\title{
Saudi Arabian IPOs Productivity and Efficiency
}

\author{
Ahmed Alanazi \\ Corresponding author, Department of Accounting, Finance and Economics \\ Griffith Business School, Griffith University, Queensland 4111, Australia \\ E-mail: a.al-anazi@griffith.edu.au \\ Tel: +61 410963 145; Fax: +61 737357760 \\ Benjamin Liu \\ Department of Accounting, Finance and Economics, Griffith Business School \\ Griffith University, Queensland 4111, Australia \\ John Forster \\ Department of Accounting, Finance and Economics, Griffith Business School \\ Griffith University, Queensland 4111, Australia
}

\begin{abstract}
The main objective of the paper is to examine the performance of Saudi Arabian firms as they make the transition from private ownership into public ownership. A sample of 13 Saudi IPOs performance is investigated. We use a data envelopment analysis (DEA) method to construct the Malmquist productivity and efficiency indices. We have found that Saudi IPOs exhibit a significant decline in the productivity after the IPO as compared to the pre-IPO level. The paper is the first to provide assessment for the clustering IPOs that occurred in the Kingdom of Saudi Arabia in recent years.
\end{abstract}

Keywords: Saudi initial public offerings; Firms' performance, Productivity, DEA method, JEL Classification Codes: D24

\section{Introduction}

The purpose of this paper is to analyse the impact of the initial public offering on the performance of Saudi IPOs as measured by productivity and efficiency. The analytical tool used is the Malmquist total factor productivity (TFP) index, which is constructed by using nonparametric linear programming methods. If Saudi IPOs possess technologies that are better in the post-IPO period than in the pre-IPO period, then we can conclude that the IPO has a positive impact on these entities performance. On the other hand, if the performance shows a decline in productivity after the IPO, we can infer that the IPO has a negative impact.

Initial public offerings can be defined as ""a first-time offering of shares by a specific company to the public" (Al-Barrak, page 1, 2005). The firm will be listed in the stock market after the issue and its shares will start trading immediately. The decision for private firms to go public is one of the most difficult decisions that a company faces in its life. It is the decision that is going to change the whole capital structure of the company, and in many cases it ends up with the ownership power being transferred and taken away from the company's original owner. It is not surprising then that the IPO 
topic has attracted the attention of scholars, investors, and decision makers. Consequently, a vast number of studies have been conducted on the IPO topic, and it has been growing at faster pace in recent years (Shen \& Wei, 2007; Pagano et al., 1998).

There are many advantages that private firms can gain by going public. These are accessing other sources of funds for current and future investments, diversification purposes, increasing the publicity and the reputation of the firm, and increasing the bargaining power with banks. However, these advantages usually come at the cost of the firm loss of confidentiality, and decision control.

Perhaps one of the most developments that happened recently in Saudi Arabia was the boom in its capital market. There are ongoing strong initial public offerings which doubled the number of the listed firms from around 70 in 2002 to 129 firms in 2009 "IPO clustering" (Tadawul, 2009). This clustering is a period of "hot market" issues, which usually characterised with an increase in the number of private firms turning into public. It is a well known phenomenon in the IPO literature in U.S, Italy and other countries (Pagano et al, 1998).

Our investigation of 13 Saudi IPOs listed in the Saudi stock exchange market (Tadawul) has revealed an underperformance after the IPO event. Productivity of Saudi IPOs has declined significantly compared to their productivity level prior to the IPO. In other words, Saudi IPOs are unable to generate the same level of output (the net-income) by utilizing their inputs (total assets, operating cost) efficiently. This result is consistent with Al-Barrak (2005) on the negative impact of the IPO on the Saudi firms' performance.

The remainder of the paper is organized as follows. Section 2 reviews the relative literature on the IPO impact on the firms' performance from developed and developing countries. The DEA method is discussed next in the methodology Section 3. Section 4 provides the data selection, sampling, and descriptive statistics. The empirical findings and analysis is provided next in Section 5. Finally, Section 6 concludes the paper.

\section{Literature Review on Firms Performance After the IPO}

Previous literature on IPOs has investigated different aspects related to the IPO movement. These aspects are the motivations and barriers for and against the IPO, the initial underpriced IPOs and the short and long run abnormal return, the variation in firms performance between pre and post-IPO performance, and theories and explanations that can explain the performance change reasons. Comparing the firms' performance before and after the IPO is one of the most studied issues in IPO literature. However, studies on the IPO topic in emerging economies are still far behind studies on developed world. This creates an obvious gap in the literature, which we are trying to address in this paper.

In regard to the firms' performance after the IPO, there is a semi agreement between most scholar articles that the IPO has a negative impact on the firms' performance. For example, Jain \& Kini (1994), and Mikkelson et al., (1997) have documented performance deterioration after the IPO among samples of U.S IPOs. A study on 180 Japanese initial public offerings by Cai \& Wei (1997) also found a strong deterioration in the post-IPO performance compared to the pre-IPO period, similar to the U.S findings by other authors.

In the European markets many papers have documented the same phenomenon of performance decline after the issue. Pagano, Panetta \& Zingales (1998) found a decline in the post-IPO performance among Italian firms. They have used a performance comparison between pre and post-IPO to conclude reasons behind firms' motivations to go public. They have found that the post-IPO performance is worse than compared to the pre-IPO level. Another study on Germany and Spain found that the family owned businesses' performance tend to decline in the long-run after joining the stock exchange market (Peter, Victor, Susana \& Dirk, 2005). Furthermore, in line with other results, a paper on 411 IPOs that took place in London stock exchange market from1995 to 1999 have shown that these IPOs were unable to sustain their superior pre-IPO performance in the aftermarket period in the U.K (Khurshed, Palerai \& Vismara, 2005). 
Not surprisingly, there is no much evidence coming from the developing world due to the undeveloped markets structure and the lack of consistent and available data. Exception to this is the study by Kenneth et al (2004) who conducted a study on Thai IPOs. The authors have found a similar pattern to the advanced economies of performance deterioration after the shares issuance, but rather a more dramatic decline. They found that the decline among Thai IPOs is ten times greater than that found in U.S.

Another study by Al-Barrak (2005) on Saudi IPOs motivations, barriers, and performance has also documented performance deterioration in the post-IPO period. Due to the sample size obstacle the author has used several techniques to study IPOs in Saudi Arabia including interviews and one thorough case study analysis on only one firm. According to Al-Barrak the firm was the only one that agreed to provide him with the required data only under a concrete condition that the firm identity should not be mentioned at any stage. This gives us a clue about how confidentiality is perceived in Saudi Arabia, the focus of this study. Al-Barrak (2005) found a performance drop after the IPO in terms of ROA, ROS, ROE, OROA, and OROS.

\section{Methodology}

In this method a different type of firms' performance measurements in terms of efficiency and productivity will be applied by using the Data Envelopment Analysis (DEA). Several authors have used this method in assessing firms' performance such as Fare, Shawan and Lee (1995) who examined Taiwanese manufacturing industries and Turhan (2004) in a study measuring Turkish cement industry. The DEA approach is a non-parametric linear programming method used for evaluating the inefficiency of a firm or the decision making units (DMUs). It measures the mix of inputs to produce outputs and calculate the firms' efficiency related to an efficient technology, which is usually represented by some forms of frontier.

This modern method started with Farrell (1957), who proposed that the efficiency of the firm compromises of two components, the technical efficiency and the allocative efficiency. Unfortunately, Farrell's paper did not receive much attention by authors for two decades until the paper by Charnes, Cooper and Rhodes (1978), who suggested a model that has an input orientation and assumes constant return to scale (CRS) technology. Input orientation refers to the question of how much the firm's output quantities can be proportionally expanded without altering the input quantities. The standard DEA method usually requires a measure at a certain point of time (cross sectional data) and does not allow a study over a time horizon. Therefore, it is not applicable for this paper purposes that is examining firms' performance over two time periods pre and post-IPO. When however, there is a suitable panel data on firms' over a time horizon, a popular method of DEA called DEA-like method was proposed by Fare et al. (1994), which we tend to use in this paper. This method is used to construct the Malmquist TFP indices. TFP is the productivity measure that involves all factors of production and in its simplest measure with one output and one input can be defined as the ratio of the output to the input (Coelli, 2005).

The most critical part in this analysis is identifying the right outputs and the corresponding inputs. The inputs usually are the commonly-used classification "KLEMS" that involves Capital (K), Labour (L), Energy (E), Material inputs (M), and Purchased services (S). Accordingly, the outputs should be representative of the firms' actual outputs, usually firms' products or services (Coelli, 2005). However, since the firms in this study belong to different industries, it is difficult to identify the operational outputs and inputs. For example, a Saudi food company would have an orange juice as one product (output), while a housing firm would be more concerned with the number of units being sold as the output. Therefore, unless a common ground is established between these firms, it will not be possible to pool them altogether.

All these firms' decisions to go public were motivated by the need to access other sources of funds for expanding operation. As a result, the firms' wealth and increasing profitability should be the common feature between these firms. Therefore, we are considering the firms' net income as the output 
in this study. The corresponding two inputs to the net income are the operating cost, and the total assets. Viverita \& Ariff (2008) in a study on Indonesian firms' productivity have used the (EBIT) earnings before interest and tax as the output to replace the net income, since some of their firms were government who do not perceive profitability as important factor as other firms. In this paper we argue that Saudi IPOs are profit seekers, especially after the IPO, because there are new shareholders who will demand dividends, and new regulations applied by the Capital Market Authority CMA that entitled these firms to maintain a reasonable level of profitability. Also, Ahmet \& Eyup (2008) in a study on the productivity of foreign companies operating in Turkey have used the net income as the output.

Firms' assets can be used as either input or output. It depends on what the researcher is willing to know. It can be used as an output in the sense that assets increase adds value to the firms' wealth accumulation. On the other hand, it can be also taken as an input when we think that assets increase alone is not an objective, instead firms usually use assets to generate income. This difference in how we perceive one input or output can give a clue as to how difficult and sensitive is the inputs-outputs selection procedure. In addition to the total assets input in this study, the operating cost will be included as the second input. Operating cost is the cost includes workers bill, renting cost, maintenance, insurance cost, general services, and other costs. Ahmet \& Eyup (2008) have identified total assets and operating cost as their inputs in measuring foreign companies' productivity in Turkey. Therefore, we adopt this in our paper.

We will measure the change of inputs-outputs of a firm at a certain time $(\mathrm{Xt}+1, \mathrm{Yt}+1)$, relative to inputs-outputs at a starting point $(\mathrm{Xt}, \mathrm{Yt})$, where $\mathrm{X}$ represents the inputs (total assets, operating cost) of the firm and $Y$ represents the output (net income). The time $t+1$ refers to the after IPO period and $t$ represents the before IPO period.

Because this method requires data on all years to be available, the sample will be divided into two groups. Group1 is all Saudi companies that went public in 2006 and Group 2 is firms that went public in 2007. Then, a comparison between the Malmquist indices before and after the IPO will be done for each group individually to see how the IPO has impacted these firms. Finally, Wilcoxon signed rank test will be applied to test for statistical significance change in the total factor productivity.

The Malmquist index is defined using distance functions. Distance functions describe a multiinput, multi-output production technology without the need to specify the behavioural objective such as cost minimization or profit maximization. Input and output distance functions can be both defined. The input one characterizes the production technology by looking at a maximal proportional contraction of the input victor, given an output vector. The output distance function considers the maximal proportional expansion of the output vector, given an input vector (Eyup \& Ahmet, 2008).

The production set $\mathrm{Pt}$, which models the transformation of inputs $\mathrm{X}$ (operating cost and total assets) into output $\mathrm{Y}$ (net income) at time $\mathrm{t}$ (pre-IPO) is

$\mathrm{Pt}=\{(\mathrm{Xt}, \mathrm{Yt}): \mathrm{Xt}$ can produce $\mathrm{Yt}\}$

The output distance function for a firm on the output set, $\mathrm{Pt}$, is:

$\mathrm{d}_{0}^{\mathrm{t}}(\mathrm{Xt}, \mathrm{Yt})=\min \{\mathrm{Xt}, \mathrm{Yt} / \theta) \in \mathrm{Pt}$

The distance function measures the reciprocal of the maximal ray expansion of the observed outputs $(\mathrm{Yt})$ given inputs $(\mathrm{Xt})$ such that outputs are still feasible in relation to production technology Pt. The distance function will take a value that is less than or equal to 1 if and only if the output and input vectors are elements of the feasible production set, $(\mathrm{Xt}, \mathrm{Yt}) \mathrm{C} \mathrm{Pt}$.

The Malmquist TFP index measures the TFP change between two data points by calculating the ratio of the distances of each data point, relative to a common technology. Fare et al., (1994) define the Malmquist (output-oriented) TFP index between period $t$ and period $t+1$ as

$\mathrm{M}(\mathrm{Yt}, \mathrm{Xt}, \mathrm{Yt}+1, \mathrm{Xt}+1)=\left[\mathrm{d}_{0}^{\mathrm{t}}\left(\mathrm{Yt}+1, \mathrm{Xt}+1 / \mathrm{d}_{0}^{\mathrm{t}}(\mathrm{Yt}, \mathrm{Xt}) \times \mathrm{d}^{\mathrm{t}+1}{ }_{0}(\mathrm{Yt}+1, \mathrm{Xt}+1) / \mathrm{d}^{\mathrm{t}+1}{ }_{0}(\mathrm{Yt}, \mathrm{Xt})\right]^{1 / 2}\right.$

Where the notation $\mathrm{d}_{0}^{\mathrm{t}}(\mathrm{Yt}+1, \mathrm{Xt}+1)$ represents the distance of the period $\mathrm{t}+1$ observed from period t technology. A value of $\mathrm{M}$ greater than 1 indicates positive TFP growth from period $t$ to $t+1$, while a value less than 1 indicates the opposite. 
Malmquist allows a decomposition of total factor productivity TFP into technical efficiency change and technological change. Table 1 illustrates the suggested inputs-output model:

Table 1: The Proposed Model for DEA-like Method Examination

\begin{tabular}{|l|c|c|}
\hline $\begin{array}{l}\text { Inputs } \\
\text { Outputs }\end{array}$ & $\begin{array}{c}\text { (1) Total Assets } \\
\text { Net Income }\end{array}$ & (2) Operating Cost \\
\hline
\end{tabular}

The final step in our analysis is using the matched pairs' approach to test for significance change in the total factor productivity. We will institute all the thirteen firms TFP together for before and after the IPO TFP to calculate the difference between these two periods. Then the Wilcoxon signed rank statistical test will be used for the median significance change and the t-student test for the mean change significance.

\section{Data and Descriptive Statistics}

\subsection{Data and Sampling}

We have relied on the secondary type of data in measuring Saudi IPOs. Neuman (2006) defines the secondary data as "data prepared by other researchers or institutions". Two sources of data have been used in this paper. Companies' performance data before the IPO have been collected from the Saudi Capital Market Authority (CMA). Any firm wishes to join the Saudi capital market must provide three years audited accounting information to investors prior to the IPO. CMA maintains these prospectuses in its database where we were able to access and collect. Data on firms' performance for the post-IPO period were collected from the Saudi Stock Exchange Market "Tadawul". Tadawul produces quarter and annual financial statements for the stock market performance in general and each listed firm individually. It maintains these reports in its database where we were able to access and collect for all targeted firms.

We restrict our sample to the period between 2003 and 2008 because it is the period when most Saudi IPOs took place, 57 companies. Firms that went public as a new establishment or start-ups were excluded because they cannot add any value to the scope of the study. Also, to avoid data incompatibility, IPOs under mergers and acquisition activities and privatization were also excluded. These filters have reduced the sample size to 13 firms.

\subsection{Descriptive Statistics}

Table 2 Panel A shows all IPOs that took place in Saudi Arabia between 2003 and 2009. Note that the number of IPOs has increased in 2006 and peaked in 2007. This period represents a clustering period in Saudi Arabia which is a period that is characterized with an increase in the number of firms shifting from private ownership into public. In Panel B we list our sample firms under consideration in this paper, their industry, the year when they conducted the IPO, and the percentage of shares being offered to Saudi investors. 
Table 2: Number of Issues in Saudi Arabia Panel A:

\begin{tabular}{|c|c|}
\hline Year & Number of IPOs (companies) \\
\hline 2003 & 1 \\
2004 & 2 \\
2005 & 5 \\
2006 & 10 \\
2007 & 25 \\
2008 & 14 \\
2009 & 5 \\
\hline Total & $\mathbf{6 2}$ \\
\hline
\end{tabular}

Panel B: Sample of the Saudi IPOs

The sample industry, IPO year and the percentage of offered shares

\begin{tabular}{|c|l|l|c|c|}
\hline & Company Name & Industry & IPO Year & Percentage of offered share \\
\hline 1 & Aldrees & Petroleum Retailers & $30 \%$ \\
2 & Saudi Paper Manufacturing & Manufacturing Investment & 21-Jan-06 & $30 \%$ \\
3 & Red Sea for Housing & Construction \& Building & $12-$ Aug-06 & $30 \%$ \\
4 & Albabtain & Construction \& Building & $4-$ Nov-06 & $30 \%$ \\
5 & Alabdulateef & Manufacturing Investment & $18-$ Dec-06 & $30 \%$ \\
6 & SVCP & Construction \& Building & 8 -May-07 & $30 \%$ \\
7 & Saudi Printing \& Packaging Co. & Media \& Publication & $30-J u n-07$ & $30 \%$ \\
8 & MESC & Construction \& Building & 5-Nov-07 & $30 \%$ \\
9 & Alkaleej & Retailers & 5-Nov-07 & $30 \%$ \\
10 & Dar Al-Arkan & Real Estate Developer & 1 -Dec-07 & $11.01 \%$ \\
11 & Al-Othaim & Retailers & 21-Jun-08 & $30 \%$ \\
12 & Halwani Bros & Agricultural and Food & 21-Jun-08 & $30 \%$ \\
13 & Chemanol & Petrochemical Industry & 11-Aug-08 & $50 \%$ \\
\hline
\end{tabular}

Source: (Capital Market Authority, Tadawul, 2009) المصادر: هيئة سوق المال السعودي, تداول

\section{Empirical Analysis}

Table 3 presents the Malmquist index values and their decomposition into technical change and efficiency change for five Saudi IPO firms. Malmquist TFP index for these five firms decreased after the IPO compared to before IPO period. The TFP value has dropped from 1.233 before the IPO to 0.954 after. Four firms have exhibited a decline in TFP, while only one firm has shown improvement. Analysing the components of the TFP to find out what caused the productivity fall among these firms, we observe that the decline is caused mainly by the technical change, while the efficiency change is surprisingly has increased. The mean for the technical change has declined from 47.1 to 05.3 per cent, which indicates that productivity fall is caused strongly by the technical change. The drop in the technical change indicates that Saudi IPO firms are unable to produce more output (generate more net income) with a given vector of input quantities (total assets and operating cost) in the post-IPO period compared to the feasible level during the pre-IPO period. Moreover, the efficiency change components (the pure efficiency change and the scale efficiency change) indicate that the slight improvement in the efficiency change is mainly attributed to the pure efficiency increase and not to the scale efficiency. 
Table 3: The Malmquist Indices for 2006 Saudi Firms group

\begin{tabular}{|c|c|c|c|c|c|}
\hline Firm & Effch & $\begin{array}{c}\text { Before IPO } \\
\text { Techch }\end{array}$ & Pech & Sech & TFPch \\
\hline Aldrees & 0.702 & 1.392 & 1 & 0.702 & 0.977 \\
\hline Paper & 0.92 & 1.384 & 1.038 & 0.887 & 1.274 \\
\hline red sea & 1 & 1.417 & 1 & 1 & 1.417 \\
\hline Albabtain & 0.642 & 1.408 & 0.8 & 0.802 & 0.903 \\
\hline Alabdulateef & 1 & 1.791 & 1 & 1 & 1.791 \\
\hline Mean & 0.838 & 1.471 & 0.964 & 0.87 & 1.233 \\
\hline Firm & Effch & $\begin{array}{c}\text { After IPO } \\
\text { Techch }\end{array}$ & Pech & Sech & TFPch \\
\hline Aldrees & 0.783 & 1.142 & 1 & 0.783 & 0.895 \\
\hline Paper & 0.752 & 1.082 & 0.957 & 0.786 & 0.813 \\
\hline red sea & 1.008 & 1.142 & 1 & 1.008 & 1.151 \\
\hline Albabtain & 1.024 & 1.041 & 1.126 & 0.91 & 1.067 \\
\hline Alabdulateef & 1 & 0.883 & 1 & 1 & 0.883 \\
\hline Mean & 0.905 & 1.053 & 1.015 & 0.892 & 0.954 \\
\hline
\end{tabular}

EFFCH is the efficiency change, TECHCH is the technical change, PECH is the pure efficiency change, SECH is the scale efficiency change, TFCH is the total factor productivity change

In Table 4, we find similar results of declining total factor productivity among Saudi firms that went public in 2007. The mean value was 96.2 per cent and after the IPO has decreased to 83.7 per cent, which is indicating productivity deterioration after the issue compared to the prior to IPO level. One interesting finding here is that within this group all indices are declining after the IPO. Unlike, the increase in the efficiency which found before within group one, in this group the efficiency change also has declined from 1.09 to 0.953 .

It seems that the increase in efficiency within group 1 was due to sample size obstacle rather than a real increase in efficiency. Also, the decline in the productivity within this group is impacted by both technical change and efficiency change, but it is more linked to the drop in the efficiency. Analysing the components of the efficiency change it is found that efficiency drop is more due to scale efficiency decline, indicating that Saudi IPO firms are operating in the wrong scale rather than a decrease in pure efficiency.

Table 5 demonstrates the total factor productivity change between the two periods before and after the IPO for both groups altogether. Thirteen Saudi IPOs' TFP are examined here by using the matched pairs' approach. It can be clearly seen from the table that the median average TFP has declined by about 9 per cent (fallen from 1.092 to 0.901 ) after the IPO compared to the pre-IPO level. Also the average mean TFP has declined by 12.68 per cent from before to after the IPO. This decline in the TFP is found to be significant at 10 per cent for the mean and median values using the Wilcoxon signed rank test for the median change and the t-student test for the mean difference. This result confirms our findings on the Saudi IPOs' performance decline.

Table 4: The Malmquist Indices for 2007 Saudi Firms group

\begin{tabular}{|l|c|c|c|c|c|}
\hline & & \multicolumn{2}{|c|}{ Before the IPO } & & \\
\hline Firm & Effch & Techch & Pech & Sech & TFPch \\
\hline SVCP & 0.897 & 0.824 & 0.916 & 0.979 & 0.739 \\
SPPG & 1 & 0.869 & 1 & 1 & 0.869 \\
MESC & 1.315 & 0.897 & 1.248 & 1.054 & 1.18 \\
Alkaleej & 1.427 & 0.875 & 1.253 & 1.139 & 1.248 \\
Dar Alarkan & 1.049 & 0.863 & 1 & 1.049 & 0.905 \\
Halwani & 1 & 1.022 & 1 & 1 & 1.022 \\
Alothaim & 1.303 & 0.863 & 1.201 & 1.085 & 1.125 \\
Kemanol & 0.866 & 0.863 & 0.859 & 1.007 & 0.747 \\
Mean & 1.09 & 0.883 & 1.05 & 1.038 & 0.962 \\
\hline
\end{tabular}




\begin{tabular}{|l|c|c|c|c|c|}
\hline & & \multicolumn{2}{|c|}{ After IPO } & & \\
\hline Firm & Effch & Techch & Pech & Sech & TFPch \\
\hline SVCP & 0.939 & 0.879 & 1 & 0.939 & 0.825 \\
SPPG & 1 & 0.908 & 1 & 1 & 0.908 \\
MESC & 0.517 & 0.879 & 0.54 & 0.957 & 0.454 \\
Alkaleej & 1.056 & 0.879 & 1 & 1.056 & 0.929 \\
Dar Alarkan & 1 & 0.816 & 1 & 1 & 0.816 \\
Halwani & 1.412 & 0.879 & 1.093 & 1.292 & 1.241 \\
Alothaim & 1.064 & 0.879 & 1.044 & 1.019 & 0.935 \\
Kemanol & 0.881 & 0.91 & 1.043 & 0.845 & 0.802 \\
Mean & 0.953 & 0.878 & 0.946 & 1.007 & 0.837 \\
\hline
\end{tabular}

Table 5: $\quad$ The Change in TFP among Saudi IPO firms

\begin{tabular}{|l|c|c|c|c|}
\hline Firm & TFP before IPO & TFP after IPO & Difference & Difference as \% \\
\hline Aldrees & 0.977 & 0.895 & -0.082 & $-8.39 \%$ \\
Paper & 1.274 & 0.813 & -0.461 & $-36.19 \%$ \\
red sea & 1.417 & 1.151 & -0.266 & $-18.77 \%$ \\
Albabtain & 0.903 & 1.067 & 0.164 & $18.16 \%$ \\
Alabdulateef & 1.791 & 0.883 & -0.908 & $-50.70 \%$ \\
SVCP & 0.739 & 0.825 & 0.086 & $11.64 \%$ \\
SPPG & 0.869 & 0.908 & 0.039 & $4.49 \%$ \\
MESC & 1.18 & 0.454 & -0.726 & $-61.53 \%$ \\
Alkaleej & 1.248 & 0.929 & -0.319 & $-25.56 \%$ \\
Dar Alarkan & 0.905 & 0.816 & -0.089 & $-9.83 \%$ \\
Halwani & 1.022 & 1.241 & 0.219 & $21.43 \%$ \\
Alothaim & 1.125 & 0.935 & -0.19 & $-16.89 \%$ \\
Kemanol & 0.747 & 0.802 & 0.055 & $7.36 \%$ \\
Mean & 1.092 & 0.901 & -0.190 & $-12.68 \%$ \\
Median & 1.022 & 0.895 & -0.089 & $-9.83 \%$ \\
\hline
\end{tabular}

Figure 1 shows the line graph for the total factor productivity TFP for the examined 13 Saudi IPO firms. It can be clearly seen that the TFP in the after IPO period is lower than the before IPO period.

Figure 1: Line graph for the TFP before and after the IPO

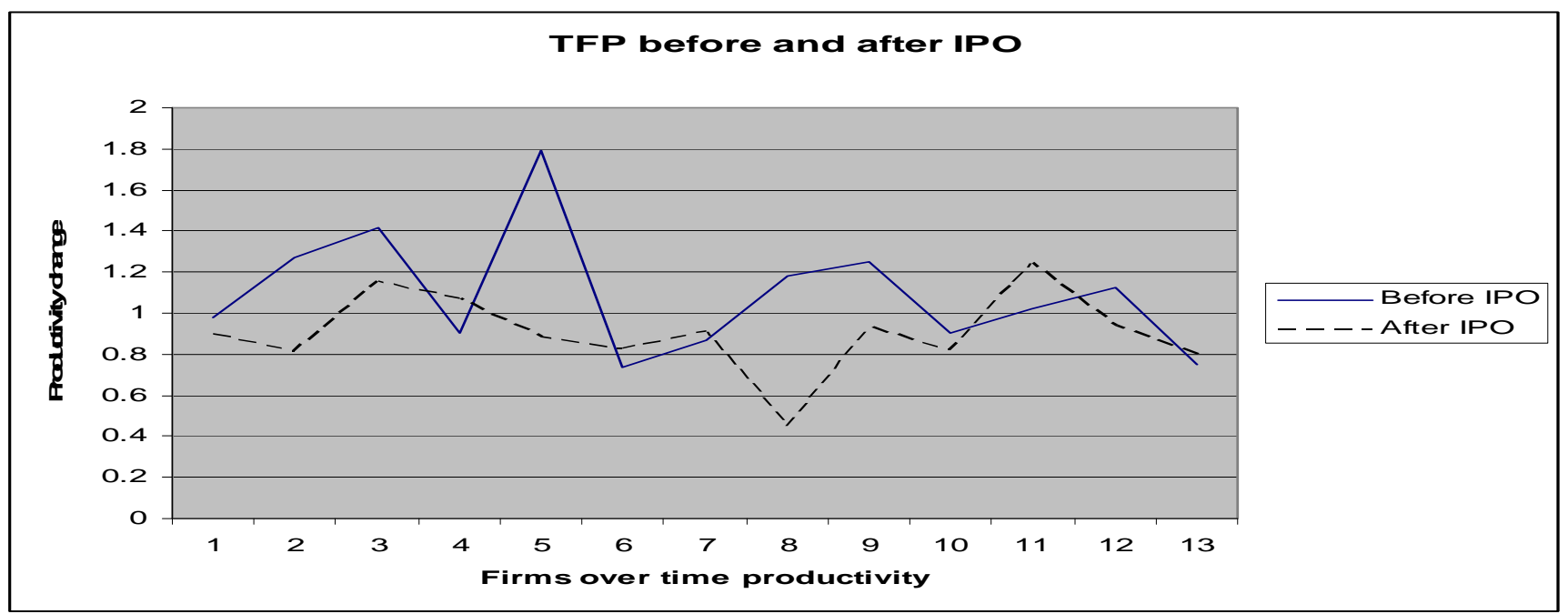




\section{Conclusion}

In this paper, the performance of thirteen Saudi firms that transformed from private ownership into public ownership was examined. The IPOs performance has declined significantly after the IPO as measured by productivity TFP using the Malmquist DEA method. Nine Saudi IPOs has experienced improvement in efficiency but are not significant at any level of significance. This result of performance decline is consistent result with many authors in the IPO literature from both developed and developing countries such as Jain \& Kini (1994), Kenneth et al., (2004), Changyun (2005) and AlBarrak (2005).

In this paper we have used a different method of measuring firms' performance but came up with the same findings of the negative impact of the IPO on the performance.

\section{Reference}

[1] Al-Barrak, A. (2005), "Initial Public Offerings in Saudi Arabia: Motivations, Barriers, and Effects". PhD Thesis, Accounting and Finance Department, University of Newcastle upon Tyne

[2] Cai, J., and K.C. J. Wei, (1997), "The investment and operating performance of Japanese Initial public offerings." Pacific-Basin Finance Journal Vol.5, pp.389-417.

[3] Charnes, A., Cooper, W., \& Rhodes, E. (1979), "Measuring the efficiency of decision-making units". European Journal of Operational Research, 3(4), 339-339.

[4] Capital Market Authority "CPA", Available: هيئة سوق المال السعودي http://www.cma.org.sa الألكتروني الرسمي

[5] Coelli, T., D.S. Prasada, Christopher J., George E. (2005), An Introduction to Efficiency and Productivity Analysis ( $2^{\text {nd }}$ edition). Boston; Spring street; NY: Springer Science Publisher

[6] Coelli, T. " Efficiency \& Productivity Analysis (Workshop) course" 3 days. Centre for Efficiency and Productivity Analysis, QLD, Australia, School of Economics, University of Queensland, (1-3 October, 2008).

[7] Eyup B, Ahmet, A.(2008), "The Comparative Productivity of the Foreign Owned Companies in Turkey: A Malmquist Productivity Index Approach". International Research Journal of Finance and Economics. ISSN 1450-2887 Issue 22

[8] Färe, R., Grosskopf, S., Norris, M., \& Zhang, Z. (1994, March), "Productivity Growth, Technical Progress, and Efficiency Change in Industrialized Countries". American Economic Review, 84(1), 66-83.

[9] Fare, Rolf, Grosskopf, Shawna, Lee, Wen-Fu. (1995), "Productivity in Taiwanese manufacturing industries". Applied Economics, 27(3), 259.

[10] Farrell, M.J. (1957), "The Measurement of Productive Efficiency". Journal of the Royal Statistical Society. Series A (General), 120, no.3: 253-290.

[11] Jain, B. A., Kini, O. (1994), "The post-issue operating performance of IPO firms". The Journal of Finance, 49(5), 1699.

[12] Kenneth, K., Pattanaporn, K., and John, R. N. (2004), "Ownership and Operating performance in an emerging market: evidence from Thai IPO firms". Journal of Corporate Finance, 10, 355381

[13] Khurshed, A., Paleari, S., and Vismara, S. (2005), "The Operating and Share Price Performance of Initial Public Offerings: The UK Experience". Available at SSRN.

[14] Mikkelson, W. H., Partch, M Megan, Shah, K. (1997), "Ownership and operating performance of companies that go public". Journal of Financial Economics, 44(3), 279-307.

[15] Neuman, W.L. (2006), Social Research Methods: Qualitative and Quantitative Approaches (6 ${ }^{\text {th }}$ ed.). Boston: Pearson Education

[16] PAGANO, M., PANETTA, F., \& ZINGALES, L. (1998), "Why Do Companies Go Public? An Empirical Analysis". Journal of Finance, 53(1), 27-64.

[17] Peter J, Víctor M. G., Susana M., \& Dirk, S. (2005), "Long-Run IPO Performance Analysis of German and Spanish Family-Owned Businesses". Family Business Review, 18(3), 179-202. 
[18] Saudi Stock Exchange “Tadawul”, Available: سوق المال السعودي, تداول Sttp:/www.tadawul.com.sa الموقع الألكتروني لسوق المال السعودي

[19] Turhan, A. (2004), "Enterprise performance and privatization". Ph.D. dissertation, George Mason University, United States -- Virginia.

[20] Viverita, M. Ariff (2008), "On Productivity Performance Gains of Indonesian Firms". CARFF-136. Working paper.

[21] Shen, Y., \& Wei, P. (2007), "WHY DO COMPANIES CHOOSE TO GO IPOS? NEW RESULTS USING DATA FROM TAIWAN". Journal of Economics and Finance, 31(3), 359367. 